\title{
RE (VIEWING) THREE-DIMENSIONAL WORLD OF PAKISTAN'S FOLK THEATRE ARTIST IN SAEED'S FORGOTTEN FACES: A PSYCHOANALYTICAL CRITIQUE
}

\author{
Amna Aziz $^{1 *}$, Aniqa Rashid ${ }^{2}$, Aqsa Aslam ${ }^{3}$, Iqra Nazish ${ }^{4}$, Khadija Majeed $^{5}$ \\ $1^{*, 3,4,5}$ Lecturer, National University of Modern Languages Islamabad, Pakistan; ${ }^{2}$ Assistant Professor, National University \\ of Modern Languages Islamabad, Pakistan. \\ Email: ${ }^{1 *}$ amnaaziznuml@gmail.com, ${ }^{2}$ anrashid@numl.edu.pk
}

Article History: Received on $21^{\text {st }}$ May 2021, Revised on $29^{\text {th }}$ May 2021, Published on $1^{\text {st }}$ June 2021

\begin{abstract}
Purpose of the study: This study contextualizes within the border of psychoanalytical perspective specifically focusing on Freud's theory of personality and Lacan's module of the psyche to evaluate an artist's mental state that how his/her mental state fluctuates.

Methodology: Bali Jatti is taken as an exemplary character to project the reality of being an artist. This analysis presents her three-dimensional world, real, theatrical, and psychological, to represent the challenges she faces as she opts to embrace the life of folk theatre. It explores her psychological life and the chaos in which she spends the rest of her life. It probes into social taboos and stigmas that are associated with her life that makes her a stereotypical icon.
\end{abstract}

Main Findings: This research concludes that the psychological world of folk theatre Bali is under the hegemonic supremacy of the other two worlds, real and theatrical. This diligent inquiry leads the reader through a steady stream of events of Bali's life which is taken as an exemplary character to project the reality of being an artist.

Applications of this study: This study provides guidelines to academia and probes into an exploration of the novel concept of Pakistan folk theatre and its artist's three-dimensional world.

Novelty/Originality of this study: From a theoretical perspective, this study provides important insights into literature by exploring the most demanding skills in folk theatre artists and their three-dimensional world that formulates their destiny and takes their journey of life from glory to demise.

Keywords: Psychoanalysis, Pakistan's Folk Theatre, Artists, Three-Dimensional World, Critical Representation.

\section{INTRODUCTION}

Asian Theatre or Folk theatre was started in the world after Second World War (Liu, 2016). It is composed of an amalgam of chunks of music, dance, versification, epics and ballads, and representation of plastic art, religion, and festival peasantry. It is known as people's theatre. It has roots in a native culture, which is lodged solidly into local identity and social values. This was the only significant source of entertainment for the rural masses, especially in the post-harvest season. Folk theatre is also known as nomadic or outdoor theatre that people have always been less appreciated. Folk theatre has been used to propagate critical social, political, and cultural issues in theatrical performances to convey messages for people's awareness. These outdoor street theatres have been a significant showcase of real-life experiences that are executed in the form of performances (Harris, 2004). Theatrical activities in Pakistan started when Pakistan came into existence in 1947 and propagates Pakistan's socio-political issues (Bibi et al., 2021). From independence to the recent scenario, many theatre groups emerged and were banned due to social problems. Subject and context are simple in folk theatre because most stories are related to their local regions. A Forgotten Faces is taken as a core text to emphasize the significance of the present study.

Forgotten Faces is a document written from a historical perspective to make its reader aware of performing arts that are deeply linked with the culture and traditions of Pakistan that were later ignored by people. In 1960-70, Theatre in Pakistan had faced a decline due to the emergence of electronic media (Rashid, 2015). This work is a tribute to those folk theatre artists who were associated with folk theatre in early times when electronic media was not as common today. Bali Jatti's life is portrayed as a realistic and exemplary icon to unravel the reality of an artist's life and its hardships for being a theatre artist. This research explores the lives of different folk theatre artists of Pakistan. The major objective of the present study is to unravel the three-dimensional world of Bali Jatti. This problem statement reveals that Bali's realworld and theatrical world is under the hegemonic supremacy of the psychological world. This collapse between these worlds destined the journey of Bali life from glory to decline. It makes its reader aware of the folk theatre of Pakistan, which faced demise, and so on the artists.

Forgotten Faces tremendously focuses on the life of a well-renowned folk theatre artist Bali Jatti. Jatti was the actress who spent her whole life promoting Pakistani Folk Theatre willingly and unwillingly. Saeed portrays Jatti's life as an example that sets the trend in theatre and reveals her apparent fame full of emotional tragedies and violence, which gradually destroy everything in her life. She was the first Pakistani theatre actress who owned a traveling stage theatre in Punjab, Pakistan. She was not aware of the consequences of being a theatre actress because she came into this field due to her husband, who forced her to join this profession. That was the only reason she kept her daughter Abida Jatti far 
away from this profession. She always kept her children away from this profession because she knew well about those stigmas with, she married.

Relation of the psychological world and humans cannot remain aloof from each other (Jung, 2016). Social hierarchies and stigmas associated with this profession of pomp and show take artists' journey of life into the ambivalent situation of "to be or not to be," which is an essential aspect of the present phenomena that reveals unseen certainties of their lives. How an artist becomes the prey of social hierarchies and its role in formulating folk theatre artists' destiny. To understand the three-dimensional worlds of artists, Freud's theory of personality explained by Lindzey \& Hall (1965), which revolves around the concept of id, ego, and superego with the assimilation of Lacan's idea of real, imaginary, and symbolic from psychoanalytical perspective is taken as a lens to see the worlds of folk theatre artists.

\section{The Research Gap and objective of the study}

This inquiry investigates the clash between these three components in which the superego dominates over the id and ego. Id occupies the second position in this and remains moderate, but ego is repressed. It finds no satisfaction and balance. This thing creates an imbalance between all these three components which becomes the reason for a person's psychological disturbance and disorders. The psychoanalytical critique of Forgotten Faces adds a new perspective in this research to review the three-dimensional worlds of Pakistan's folk theatre artists.

Following Research gaps are to be identified to strengthen the significance of the present study.

Q 1. How do three worlds: Real, Theatrical, and Psychological formulate the destiny of Pakistan's folk theatre artists in Saeed's Forgotten Faces?

Q 2. How do artists' three-dimensional worlds clash with each other, and how the psychological world has hegemonic supremacy over real and theatrical worlds?

\section{LITERATURE REVIEW}

The literature review includes a survey of the topical and historical trajectory of the discipline of Pakistan's Folk Theatre and narrows it down to the literature review of the present study on Forgotten Faces to identify the gaps and justify the significance of existing research. The main concern is to disclose Pakistan's folk theatre and its artists' three-dimensional worlds by analyzing characters psychologically by taking Freud and Lacan's psychoanalytical perspective and Bali Jatti's character as an exemplary icon to project the project reality of being an artist.

Theatrical activities in the subcontinent were at their peak in the era of British colonial rule. There was an environment of promoting art and skills hidden in people. Mutually Muslims and Hindus were contributing to this field. In 1947, Pakistan got its own identity and came into its existence from where a new era of evolution started. To promote art and literature, Government College Dramatic Club (GCDC) in Lahore played a vital role in dramas of Ibsen, Shaw, and Gogol performed by local artists in both English and Urdu languages (Mason, 2016, p.270). Despite all, Theatre in Pakistan had a tough time because the government had put many objections on theatre that they were propagating such things that should not be part of an Islamic country. In the Zia Ul Haq period, which is known as a highly controversial political period, many parallel theatres were working like street theatres (Mason, 2016). Many other groups of theatre are Punjab Lok Rehash, Ajoka Theatre, Sanj, and Naya Theatre. These theatres are parallel, and most of the time, they remained on public donations for their survival (Mason, 2016).

Zaidi (2011) depicted that "Forgotten Faces" is a commitment of a journey in which the reader continues its journey towards well-renowned artists of the country with the author's collaboration. This investigates different hidden realities of Folk theatre and its artist's life from which people are not aware. These artists are the asset of our country that has forgotten by people. Furthermore, "The book is a collage of our artists, our culture and traditions. It paints the picture of the world of these artists inwards" (Zaidi, 2010).

Kamal (2012) penned down a review of Forgotten Faces with the title "Odd to the Theatrewallis." She depicts that the book explores the world of theatre and its popularity in which male and female artists are the primary concern. This is a historical document that highlights the lives of artists that have not been explored in the past, and this book is a collage of theatrical activities that have become extinct over time. This document is revived of folk culture and a tribute to those folk theatre artists who are part of this book. These artists were not given their due credit. Being artists, they suffered a lot, and many stigmas got associated with them. The core responsibilities of these artists were to promote culture and explore art and entertainment for the people of Pakistan. These above-mentioned circumstances lead these artists towards complexities that were never sought out later (Khan, 2006).

Despite encouraging artists and supporting them, our government is also neglecting these artists and their contributions. Government should support folk artists because they are not just entertainers, they are professional artists, and this is their only source of occupation. But in Pakistan, artists are in a pathetic situation even they are dying because of hunger, and no one is paying attention to them. In the end, it shows how a story ends. Folk theatre was a dominant culture in the sub-continent that people overlooked with time (NISAR, 2018). 
According to Davis (2007), all the theatres of power pretend that they are silent when it is gender representation. This is the only reason that all-female theatre artists were leading fragmented lives in which they were fighting a war between their mind and body just because they were associated with the stigmas of being an artist. Jatti was an example of the folk theatre of the sixties when the theatre was nomadic and no other entertainment source for local masses (Mubarak, 2015).

A popular actress who also was an owner of a theatre herself was Bali Jatti. This form of theatre entertainment was mobile and moved from village to village; it was more popular in the sixties and seventies. Most of the villages did not have electricity or television or cinema access (Mubarak, 2015).

Dean (1952) illustrated, "Being an actor is the loneliest thing in the world. You are all alone with your concentration and imagination, and that's all you have". In this profession, in the end, the artist remains alone, and the reason is social stigmas associated with him/her that later take him to a stage where he quits. According to Paul Valery, "An artist never really finishes his work; he merely abandons it."

The psychoanalytical theory is used to evaluate such thoughts and behavior of a character in a literary work to understand the unconscious side of their personality.

The theory is used to analyze one or more of the characters; the psychological theory becomes a tool to explain the characters' behavior and motivations. The more closely the idea seems to apply to the characters, the more realistic the work appears (McLeod, 2008).

Freud and Bonaparte (1954), known as the father of psychoanalysis, have divided the mind into three parts: id, ego, and superego. The ego is our conscious self and 'Secondary process thinking' (Freud \& Bonaparte, 1954). It develops contact with the external world that is real and controls all the functions and disorders, which create an imbalance in establishing contact with the external world. For a person's reorganization, it's a very important factor that a person should have a healthy relationship with his surroundings, and his ego should be balanced. The third is our superego that is conscience which develops a sense of right-doing or wrongdoing and 'representation of our societal rules, morays, taboos, etc.' (Freud \& Bonaparte, 1954). Superego is concerned with social models and integrities (Wang, 2020).

Lacan et al. (1993) reinterpreted Freud's most of the work from a new perspective similar to Freud's work. Lacan's most of the work is from a structuralist and post-structuralist perspective. His work's basic idea was to explore humanism, which paves a person's self-freedom and self-determination. Lacan's real, imaginary and symbolic relates with Freud's id, ego, and superego. Freud tries to strengthen the ego of a character, the real 'I' of a person. "The Real is unsayable, and, as such, it embodies the desire" (Malone \& Friedlander, 2000).

This research tends to include a novel idea in the previously established critique of folk theatre by exploring the threedimensional worlds of Pakistani folk theatre artists, namely real, theatrical, and psychological.

\section{METHODOLOGY}

The present study is qualitative. It is the profound study of Saeed's Forgotten Faces, and the mode of study is textual analysis. This text is being designated by keeping in view the relevance regarding the issues of the present study. The theoretical framework of the study is the psychoanalytical theory that covers two theorists, Freud and Lacan. This tends to explore three-dimensional worlds, real, theatrical, and psychological, of Pakistani folk theatre artists. To achieve the purpose of research, Freud is taken as an essential and chief mentor for his ideas on psychoanalytic perspective with the collaboration of Lacan's module of the psyche (Imaginary, mirror stage, and symbolic order). For the humanist, Freud is an epic poet and a hero of literature. He is known as "Darwin of the mind" (Sulloway, 1992).

Freud considered Id as "true psychic reality" Because this is a real representation of the inner world of a person and distinguishes his desires and thoughts from the outer world (McLeod, 2016). The id of a person lies on the pleasure principle; this principle creates a continuous tension between their desires which they demand to be fulfilled (Cherry, 2016). In contrast, ego lies on the reality principle, which is concerned with external realities of the world that a person faces and demands from a person to balance his desires and thoughts in the presence of outer elements that we call reality principle (Hall et al., 1957).

Lacan presents three orders or dimensions in a person's psyche. Real, Imaginary, and Symbolic order. These three orders are equally important in the formation of subjectivity and man's ideals (Nobus, 2013). The real is easiest to define but hardest to talk about. It is even impossible to talk about things freely. Real becomes real for someone and becomes the truth. We are used to the real. The reality we repress because the truth is always disturbing. Same with artist's life, they hide their identity to save them from social criticism, but a time comes when that imagined identity becomes a truth for people. That remains a truth for people, but this truth becomes disturbing because he is not what people are thinking for him. Imaginary order is concerned with the recognition of someone and his image in the mirror. The self-image that causes identification and recognition is fiction that someone can never attain. This concept relates to the artist's theatrical world, where he comes to know about many realities about this profession and himself. Still, he cannot do anything except imagining himself in this fictitious world for his recognition. Symbolic is concerned with the dimension of 
symbolization to which extent a person speaks. Symbolic is a structure of relations rather than things. These relations in artists' lives are also symbolic because social desires overcome in their life that they have to follow at any cost.

\section{RESULTS/FINDINGS}

The analysis and discussion of the present study are based upon the analysis of the three-dimensional world of Pakistani Folk theatre artist which is real, theatrical, and psychological in Saeed's Forgotten Faces. The main concern of the discussion is to critically evaluate the three-dimensional world of Bali Jatti that formulates her destiny for being an artist. The clash between these three worlds collapses her whole world, taking her journey of life from glory to demise.

This present discussion is a triangle between the three worlds of artists and the theory of personality (id, ego, and superego) to make a clear view about the three-dimensional worlds of an artist. The assimilation of Lacan's idea of real, imaginary, and symbolic, strengthens this scrutiny. This discussion's foremost focus is on the psychological world of artists, which reveals about character's psychological condition and the clash between these worlds that formulate their destiny.

\section{Real, Id, and Real World}

Real-world island of concrete practices and experiences which exist in every person's life. A person is a true product of this real land where society and external forces link with man and transform a man into the desired form, which is fittest to society. A person has to follow life's instructions; otherwise, he will be marginalized. In the real world, everything exists in reality, which cannot be denied. The world is a word that has a broad meaning. This world is about human civilization in which a person cannot remain aside from its circle. Real-world relates with Id because Id is concerned with its desires only. The same case is with the real world. The Real-world is a world that has liberty, and it goes beyond limits without any barriers. It is autonomous like the Id of a person. The Id is the unorganized part of the psyche that contains a human's instinctual drives (Siegfried, 2014). Lacan's concept "Imaginary" is concerned with the demands of a person that is the id of someone. Both ideas fall into the same category. For Lacan, imaginary means a condition that lacks any definite centre of self (Eagleton, 2011).

This research has a deep link with the real-life of artists who are concerned about this research. Id resembles Lacan's undeveloped and imaginary self. Real-life corresponds with id because real life also doesn't compromise over things and circumstances. It deals with something in which everything flows according to its desired direction, not from the required direction. There are no demands and no complaints in real life. Life does not ask for a reason and does not teach before testing you. "You don't get explanations in real life. You just get moments that are, utterly, inexplicably odd" (Reed, 2008).

Id cannot be separated from Bali's real life. Artists come in this field willingly, and only a few come unwillingly, but when they enter this field, they find themselves comfortable with this profession in the start but gradually when they come to know about the reality of this world than they find themselves unhappy and uncomfortable person of this world. The same case was with Bali. She is a phenomenal character in Saeed's book, and about her, she writes that she is the legendary artist of Pakistani Folk theatre artist who was brave and exceptional as well. According to Saeed, Her life is divided into two worlds. One is a real or personal world, and the other is a professional or theatrical world. Her character is shown as the most sympathetic character of her work that was very unstable in her real life. She was not satisfied with her life and profession. "Most women working in the theatre did not join this field of their own free will. They were generally brought into theatre by their fathers or husbands" (Saeed \& Wasti, 2011).

That's why the Id of Bali is suppressed while the id of her husband is dominant. She does not want to join this profession, but her husband forces her to join this profession. Her husband was also an artist playing minor roles in different theatres, but he did not get prominent roles and fame like other artists. So, like other male artists and theatre owners, he decided to bring her wife into this field. Munir was sure that "A young and charming wife would ensure a lucrative and successful future" (Saeed \& Wasti, 2011).

This was Jatti's id that took her towards her immediate fulfillment of desire, about which she was not aware of what will be next after taking this step. She had no option except to accept the terms and conditions of Munir to spend the rest of her life peacefully. Munir's id was to use her as a puppet to become wealthy like other theatre owners. It was a dominant trend that all theatre owners got marry to leading female artists of theatre for their benefits. Once they marry, they will not pay the amount to those actresses who are their wives now.

Similarly, Bali became a sign of victimization, and she was compelled to follow her husband's instructions at any cost. Id pulls both characters into unbearable circumstances in which survival was only possible if they keep going in life as they are doing before. Bali's return from this world became impossible because, day by day, circumstances were becoming worse.

Here, Lacan's concept of real relates with Bali's real world, and this real is someone's repressed desire that is easiest to show but hardest to say. Bali's most desires remain unfulfilled because she comes to know that this is real life where a person has to follow its rules at any cost. The real world's picture comes in front of her when she leaves her father's home for Munir. After that, she realized that this world is a world of man, not for women, and she starts hating every 
man in this world. She never thought that she would get this reward from Munir for her loyalty and love. He was used to beating her because it was his thinking that the woman remains in control of the man after doing so. It was Munir's id that he took things and circumstances from a different angle for satisfying himself.

Jatti faced so much torture at the hands of her husband, Munir Ahmed. It's difficult for many men to digest their wives' fame. Hence, such husbands tend to get abusive to ensure that they have control over their wives' assets and money (Saeed \& Wasti, 2011).

Bali's id was that she wanted her husband to be with her family. Society's fear and her id were working parallel. Her emotional and unconscious decisions were making her life hell day by day. Despite accepting Munir, she must have taught her lesson that he is not a man; he is a coward who depends on her wife's earnings. Munir is a person who sells her wife's prestige for the fulfilment of his yearnings. Later this wrong and immediate decision of Bali, Munir emerges as a sphinx that attacks his family first. This concludes that despite being a famous artist, her Id is repressed in many ways, including Munir's behavior towards her. Her repressed desires are also a reason for victimization.

\section{Imagery, Ego and Theatrical World}

The theatre world is a world of profession where reality collides with the imagined world, which is merely a fictitious world (Westlake, 2017). This life is quite different from the real world of artists. The Theatre world demands perfection because a person has to be perfect; otherwise, survival in this field is impossible. This field of showbiz is the name of variation. Changes occur rapidly in which newcomers in this field take the place of old ones. This is a ritual of this profession. The ego is based on the reality principle. The ego understands that other people have needs and desires and that sometimes being impulsive or selfish can hurt us in the long run. It's the ego's job to meet the id's needs while taking into consideration the reality of the situation. The mirror stage is ego for Lacan because it gives a fictive sense of unitary selfhood. It is ego for Lacan because it is concerned with the self-recognition of a person.

According to Freud, Ego is "Cognitive and perceptual skills that distinguish fact from fantasy" (Freud, 1924). The ego develops a perspective of reality in a person's personality. The dominance of ego in a person keeps him in the real world and far away from fantasy. The same can be seen in Bali's character if she does not run away from her home, then she would not have to bear the worst circumstances of her life. Maybe she would not have become an artist. Her life may remain honorable. But it was only possible if she had taken the right decision at the right time, and her ego would have been dominant at that time. Ego did not play a significant role in her real world. Still, it will try to play a significant role in the theatrical world where Bali will keep her prestige more important than portraying herself as a submissive character. But in the end, all incidents would refer to this thing that her ego is also repressed.

Bali's ego becomes dominant at that time only when she comes into the world of theatre. She decides to keep this profession to maintain her prestige in front of people and audiences. She will not portray her previous life in front of people at any cost. Her past was regret for her, and now she wanted to hide this harsh reality of her life from people. She pretended herself as a courageous lady who was working with many men and was leading them. Here, Lacan's concept of imaginary emerges as a supportive concept to the ego because imaginary is concerned with someone's realization about his identity and where a person comes to know about his reflection. This is the world where Bali comes to know about herself that she is not that much weak as her husband thinks. She is a courageous lady that can beat everyone in this profession. She will not allow anyone to repress her. This journey of Bali from regret to courage was not easy because she faced a time of turmoil that her husband showed her. These problematic moments motivated her to be the heroine of her life too. A time came when she became a most leading and popular artist of theatre, and her demand was at its peak from producers. "She was a woman with many talents and dared to fully take on this male-dominated theatre world" (Saeed \& Wasti, 2011).

Her real-world and theatrical worlds were colliding with each other at the same time. She has four children now, and she had to feed them, and her husband was also a burden for her. Violence and victimization, which she was facing at home, were interrupting her professional world as well. Many times, she had many wounds on her body that Munir gave her, but she did not leave her work. Because she had no other option or worked to earn money for her family's survival, that was the reason she was facing exploitation. But she always tried to take away her real-life miseries from her professional world. "She threw herself with all her remaining strength into her profession" (Saeed \& Wasti, 2011).

To maintain her ego and her survival in this profession, despite wounds, she continued working and put all her remaining efforts into it. She wanted to earn money respectably to feed her family. This strength took her from the side role actress to the heroine. Her admirer started chasing her village to village to see her live performances. Many wealthy admirers approached her and wanted to meet her alone, but she refused because she wanted to work with honor, not with this stigma of being a bad woman. Once a magistrate saw her and became a fan of her beauty. He approached her and called her to the police station to see her face. Bali went there in veil. He was not expecting this thing from an actress. He insisted she shows her face. This was her ego that was not allowing her to surrender. But Bali again refused to show her face, making the magistrate surprised why a stage artist did not want to show her face. Bali became furious over his stupidity, and she said to him, "You may be the magistrate of this place, but I am the magistrate of the stage" (Saeed \& Wasti, 2011). 
Her real and theatrical worlds collided with each other, and similarly, there was continuous war between her and her husband's id and ego, which created discrepancies in these two worlds. Bali could not balance her personal and professional life because she shared herself with society, and society never optimistically favors an artist.

\section{Symbolic Order, Super Ego and Psychological World of Bali}

The psychological world is the realm of the mind where everything matters. This world is far above than real and professional world of a person. It can be compared with a huge sphere where these two are like massive stars, and the psychological world is like a bigger planet than all that occupies more place. The world of mind takes everything under its spell.

The psychological world of a folk theatre artist is ruling over the other two worlds, which brings a clash. This world becomes a reason for their demise because they think everything very deeply, which happens due to the other two worlds. Artists are a sensitive creature of this world who examines everything deeply than others. They are art admirers and art lovers; that's why their literary sense makes them more privileged than others. But ordinary people hold their vision according to the given limitations of the world. Like Schopenhauer says, "Every man takes the limits of his field of vision for the limits of the world" (Schopenhauer, 1942).

Superego refers to the realization of social norms, values, and social taboos. It gives two dominant concepts. First is the realization of self-conscience, and second, it rebukes ego when a person violates social norms. Superego and ego play an important role in building a person's personality. At the same time, it controls the needs of the id, which should be fulfilled on a fixed time of requirement while symbolic order is changed from superego and the main difference between them is that Symbolic order refers to the pre-given structure of social roles.

The psychological world of artists can be compared with the superego from many perspectives which are hidden yet. The concept of right and wrong develops very late in artists' lives. When they take the first step in showbiz, they are not aware of the circumstances and realities behind the stage, and when they come to know about this, they get involved in many psychological disorders. They face many psychological issues like alienation, repression, depression, and regret. These all are those issues they face from the first day of joining this profession, but the realization comes later.

The dominance of artists' superego makes them realize that they are not honorable and respected for being artists for people. Their first quest is for their social status, where they find themselves substandard. People love to see artists, love $\mathrm{t}$ sit with them but don't want to share their lives with them. Lacan's symbolic order is a treatment that deals with preexisting social symbols that a person comes to know later. Social institutions exist around him, but he comes to know when it comes to his mind. He starts feeling everything so deeply and tries to adjust himself according to social morals and desires where he finds himself under social and psychological pressure. He questions himself about his existence in a respected society. He finds himself alone in this world of noble people. This is the main stigma that isolates artists' community in a society that pulls them into many complex situations that hit them psychologically. Then it becomes the saddest reality of their life to be artists. This practice results in the alienation of artists in society. They find themselves a million distances apart from other people who don't belong to the theatre profession. That's the main reason which becomes an endless hardship for them. "They face hardships, social pressure, and stigma" (Saeed \& Wasti, 2011).

A stereotypical image that people have in their minds hit them badly. They know that they have no noble status in the minds of people. Social circle leaves them when they entangle with many social stigmas and pressure for giving them a reason that they are bad people by alienating them in society. Instead of all this, "They walked on the tight rope where praise and insult were in abundance" (Saeed \& Wasti, 2011).

Bali's superego is dominant over id and ego, and that's why id and ego are repressed. When the superego would be excessively dominant in a person, then a sense of guilt would be stronger. Bali's sense of guilt remains stronger her whole life. She seeks for better future for her children because she does not want her children in this field. When she left her home, at that time, Munir showed her many dreams in which he would take her to Lahore, where she can enjoy the luxuries of city life. She was an innocent girl, and she considered everything reality that was why she left her home. But when she came to Lahore, she realized that people would ask her about her home, parents, and marriage, which was not legal in her own eyes. Later, she realized that when her children and society know about her past, what they think about her. Here norms of society and ethics were dominating over her mind. She spent the rest of her life in this condition where the superego of Bali remained dominant and pulled her into many complexities.

Despite all positivity, she found herself a bad woman who is bold and born to entertain people only. She was supposed that she would take divorce from her husband because this trend was very common in the artists' community, but she never wanted to do so. "The stigma of divorce even in the comparatively liberal theatre milieu was high, and Bali could not entirely risk this break-in ritual norms" (Saeed \& Wasti, 2011).

This was her psychological world which was repressed by the other two worlds. Peace of mind can be achieved through the comfort of the heart which is impossible for these artists because their mind and heart are divided, and even their souls are tormented because of social pressure on them. This is equivalent to turmoil which destroys the psychological world of artists. But alas, Bali was a prominent figure and asset of Pakistan's Folk Theatre that must have encouraged by 
people, but it did not happen. Saeed says that "She is certainly is a woman who should be celebrated" (Saeed \& Wasti, 2011)

The data analysis indicates that an artist has a three-dimensional world; real, theatrical, and Psychological. The psychological world is the mainstream, ruling over the rest of the two with its hegemonic supremacy. The clash comes in three-dimensional worlds because Bali's and other artists' feelings and thoughts are repressed. Superego is ruling over Bali's id and ego. Once id betrayed her, but now the superego was destroying her more than id. She started thinking about herself that she is not a good lady. The stigma of being a bad woman is now her fate. She is not honorable in society, and this thing was ruling over her mind. She gave a lot of importance to society and people despite maintaining her self-respect. She sacrificed her ego to attain respect and status in society, which she thought she would get after following them blindly. This was the real loss of Bali Jatti that destroyed her journey of life, which was already under the hegemonic supremacy of the psychological world and social hierarchies. She could not maintain a balance between her psychological life and the rest of the two worlds, and this complexity in her three-dimensional world made her a miserable character. Her three-dimensional world collapsed badly and took her towards her demise. Her decline was her ultimate end, and similarly, it happened with other artists of folk theatre who could not maintain a balance between their real, professional, and psychological world.

\section{CONCLUSION}

This article concludes that exploring three worlds opens a new window of hidden perspective for its readers about Jatti's life. These three worlds formulate the journey of Jatti, which transforms an artist into a new human being who stands nowhere. The situation of to be or not to become her reason of demise. A sense of guilt always remains dominant in Jatti's life due to the dominancy of the superego in her personality that kills her ego and id somewhere in fulfillment of society's desires. Her career becomes in turmoil for the rest of her life. Her continuous and perpetual struggle to gain identity and respect from society becomes her primary goal which remains unsettled. This article concludes that there is a war between mind and society that continues till her death, where society and the superego win. So the life of an artist is very different from other people because common people have two worlds that are real and professional while artists have three worlds; real, professional, and psychological, and their psychological world is more developed than common people because an artist is sensitive in nature. The clash between three-dimensional worlds concludes dominancy of the psychological world in the form of id, ego, and superego. The superego remains more dominant over the other two, which becomes a reason for Jatti's demise. Excessive dominance of the superego drags a person into the valley of permanent regret, and then this regret never leaves. This is how artists' three worlds collapse, resulting in their journey from glory to demise.

\section{LIMITATION AND STUDY FORWARD}

There may be several studies that may have presented an artist's three-dimensional worlds; real, professional, psychological, and its interpretation but the focus of this article is on Forgotten Faces by Dr. Fouzia Saeed. This study proposed a new and hidden perspective of an artist's three-dimensional worlds and reveals a psychological world of theatre artist that remains dominant over other two worlds; real and theatrical. Social hierarchies and stigmas are associated with Jatti's life due to which she spends her whole life in the chaos that remains dominant over her mind and this collision in her three-dimensional world takes her journey from glory to demise. These are some perspectives that are important to study in future research in this area.

\section{AUTHORS CONTRIBUTION}

Amna Aziz conceptualized the study and identified the research area, and worked on the first and last section of this manuscript that includes the results section while Dr. Aniqa Rashid designed the methodology and supervised all the activity. Aqsa Aslam worked on the introduction section, and Iqra Nazish has worked on the literature review section. Khajida Majeed has assisted in results and findings. No funding is taken by the institute for conducting this present research.

\section{REFERENCES}

1. Bibi, A., Ashfaq, S., Ullah, Q. M. S., \& Abbas, N. (2021). Ajoka theatre as an icon of liberal humanist values. Review of Education, Administration \& LAW, 4(1), 279-286. https://doi.org/10.47067/real.v4i1.135

2. Dean, J., (1952). A quote by James Dean. [online] Goodreads.com. Available at: https://www.goodreads.co m/quotes/8709-being-an-actor-is-the-loneliest-thing-in-the-world.

3. Davis, C. B. (2007). Cultural evolution and performance genres: Memetics in theatre history and performance studies. Theatre Journal, 59 (4), 595-614. https://doi.org/10.1353/tj.2008.0021

4. Eagleton, T. (2011). Literary theory: An introduction. John Wiley \& Sons.

5. Freud, S. (1924). The passing of the Oedipus complex. International Journal of Psycho-Analysis, 5, 419-424.

6. Freud, S., \& Bonaparte, P. M. (1954). The origins of psychoanalysis (Vol. 216). Imago London.

7. Hall, C. S., Lindzey, G., \& Campbell, J. B. (1957). Theories of personality. Wiley New York.

8. Harris, S. (2004). 'Dancing in the streets': The aurillac festival of street theatre. Contemporary Theatre Review, 14(2), 57-71. https://doi.org/10.1080/1026716041000128665 
9. Kamal, N. (2012). Book Review: Ode to the Theatrewallis. [online] Newsline. Available at: http://newsline magazine.com/book-review-ode-to-the-theatrewallis/.

10. Khan, F. (2006). A critical stage: the role of secular alternative theatre in Pakistan. Springer. https://doi.org/10.1057/palgrave.fr.9400307

11. Lacan, J., Miller, J.-A. E., \& Grigg, R. T. (1993). The seminar of Jacques Lacan, Book 3: The psychoses 19551956. Translation of the Seminar That Lacan Delivered to the Société Française de Psychoanalyse over the Course of the Academic Year 1955-1956.

12. Lindzey, G. E., \& Hall, C. S. (1965). Theories of personality: Primary sources and research.

13. Liu, S. (2016). Routledge Handbook of Asian Theatre. Routledge. https://doi.org/10.4324/9781315641058

14. Malone, K. R., \& Friedlander, S. R. (2000). SUNY series alternatives in psychology \& Psychoanalysis and culture. The subject of Lacan: A Lacanian Reader for psychologist. State University.

15. Mason, F. (2016). Historical dictionary of postmodernist literature and theater. Rowman \& Littlefield.

16. McLeod, S. (2008). Social identity theory.

17. Mubarak, S. (2015). Dramatizing Power and Resistance: Images of Women in Pakistani and Indian Alternative Theater.

18. Rashid, T. (2015). Theatre for community development: Street theatre as an agent of change in Punjab (Pakistan). India Quarterly, 71(4), 335-347. https://doi.org/10.1177/0974928415602604

19. Reed, S. A. (2008). Through every mirror in the world: Lacan's mirror stage as mutual reference in the works of Neil Gaiman and Tori Amos. ImageTexT: Interdisciplinary Comics Studies, 4(1).

20. Saeed, F., \& Wasti, M. (2011). Forgotten Faces: Daring Women of Pakistan's Folk Theatre. National Institute of Folk and Traditional Heritage.

21. Schopenhauer, A. (1942). Complete essays of Schopenhauer.

22. Siegfried, W. (2014). The Formation and structure of the Human Psyche. Athene Noctua: Undergraduate Philosophy Journal, 2, 1-3.

23. Sulloway, F. J. (1992). Freud, biologist of the mind: Beyond the psychoanalytic legend. Harvard University Press.

24. Zaidi, S. (2010). Forgotten Faces: Book Review.

25. McLeod, S. A. (2016). Id, ego and superego. Simply Psychology, 3, 1-4.

26. Wang, J. (2020). An Analysis of Salieri in Amadeus from Freudian Personality Theory: Id, Ego, Superego. In 3rd International Conference on Interdisciplinary Social Sciences \& Humanities (SOSHU 2020).

27. Cherry, K. (2016). The Id, Ego and Superego: The Structural Model of Personality. About.com.

28. Nobus, D. (2013). Jacques Lacan and the Freudian practice of psychoanalysis. Routledge. https://doi.org/10.4324/9780203130094

29. Westlake, E. J. (2017). World Theatre: The Basics. Taylor \& Francis. https://doi.org/10.4324/9781315734729

30. Jung, C. (2016). Psychological types. Routledge. https://doi.org/10.4324/9781315512334

31. NISAR, A. (2018). Koshur Pather: The Forgotten Folk Theatre. The Fountain Pen, 1(01), 56. 